\title{
Peopling South America's centre: the late Pleistocene site of Santa Elina
}

\author{
Denis Vialou ${ }^{1, *}$, Mohammed Benabdelhadi ${ }^{2}$, James Feathers ${ }^{3}$, \\ Michel Fontugne ${ }^{4} \&$ Agueda Vilhena Vialou ${ }^{1,5}$
}

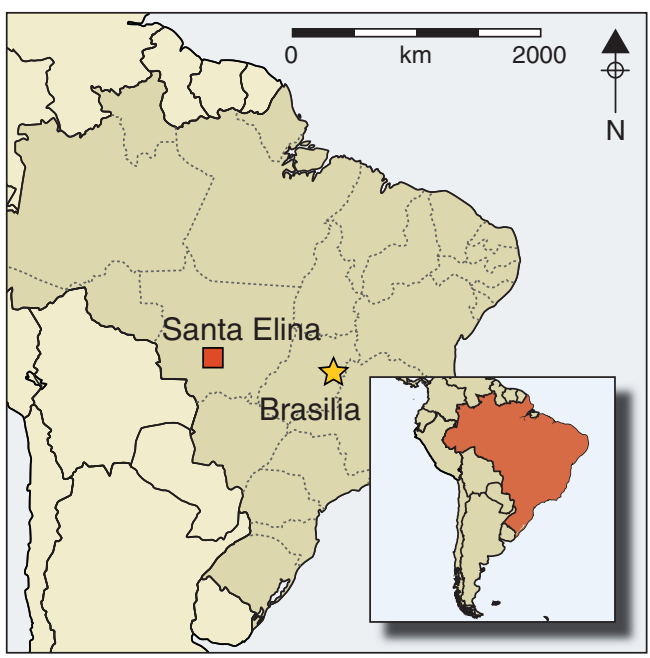

The earliest peopling of South America remains a contentious issue. Despite the growing amount of new evidence becoming available, and improved excavation and dating techniques, few sites have yet to be securely assigned to a period earlier than 12000 BP. The Santa Elina shelter in Brazil, located at the convergence of two major river basins, is one of them. The excavations at the site, including the results of various dating programmes, are described here along with reflections on the unique insights offered by Santa Elina into early migration routes into the Southern Cone.

Keywords: Brazil, Pleistocene, peopling, megafauna, lithics, OSL, U/Th, radiocarbon dating

\section{Introduction}

Although South America may have been colonised by ocean navigation several times since the late Pleistocene, the Beringian entry route remains the most widely accepted for most early American migrations. It is believed to have preceded dispersals along main river basins such as the Mississippi, Amazon and Paraná, as well as across mountain ranges such as the Rockies, the Andes, and, of course (and perhaps earliest of all), along the Pacific, and later, the Atlantic coasts (Meltzer 2009; Gruhn \& Bryan 2011; Vialou 2011).

The small number of pre-Terminal Pleistocene archaeological occupations in South America prevents us from tracing the earliest migration into the subcontinent. A widespread settlement pattern was, however, established during the final millennia of the Pleistocene.

\footnotetext{
Muséum National d'Histoire Naturelle, 57 rue Cuvier, 75005 Paris, France

Laboratory of Geo-Resources and Environment, University Sidi Mohammed Benabdallah, Fez, Morocco

Department of Anthropology, University of Washington, 314 Denny Hall, Box 353100, Seattle, WA $98195-$ 3100, USA

4 Laboratoire des Sciences du Climat et de l'Environnement, avenue de la Terrasse, F-91198 Gif-sur-Yvette Cedex, France

5 Universidade de São Paulo, Avenida Prof. Almeida Prado 1466, São Paulo, SP 05508-900, Brazil

* Author for correspondence (Email: dvialou@mnhn.fr)
} 

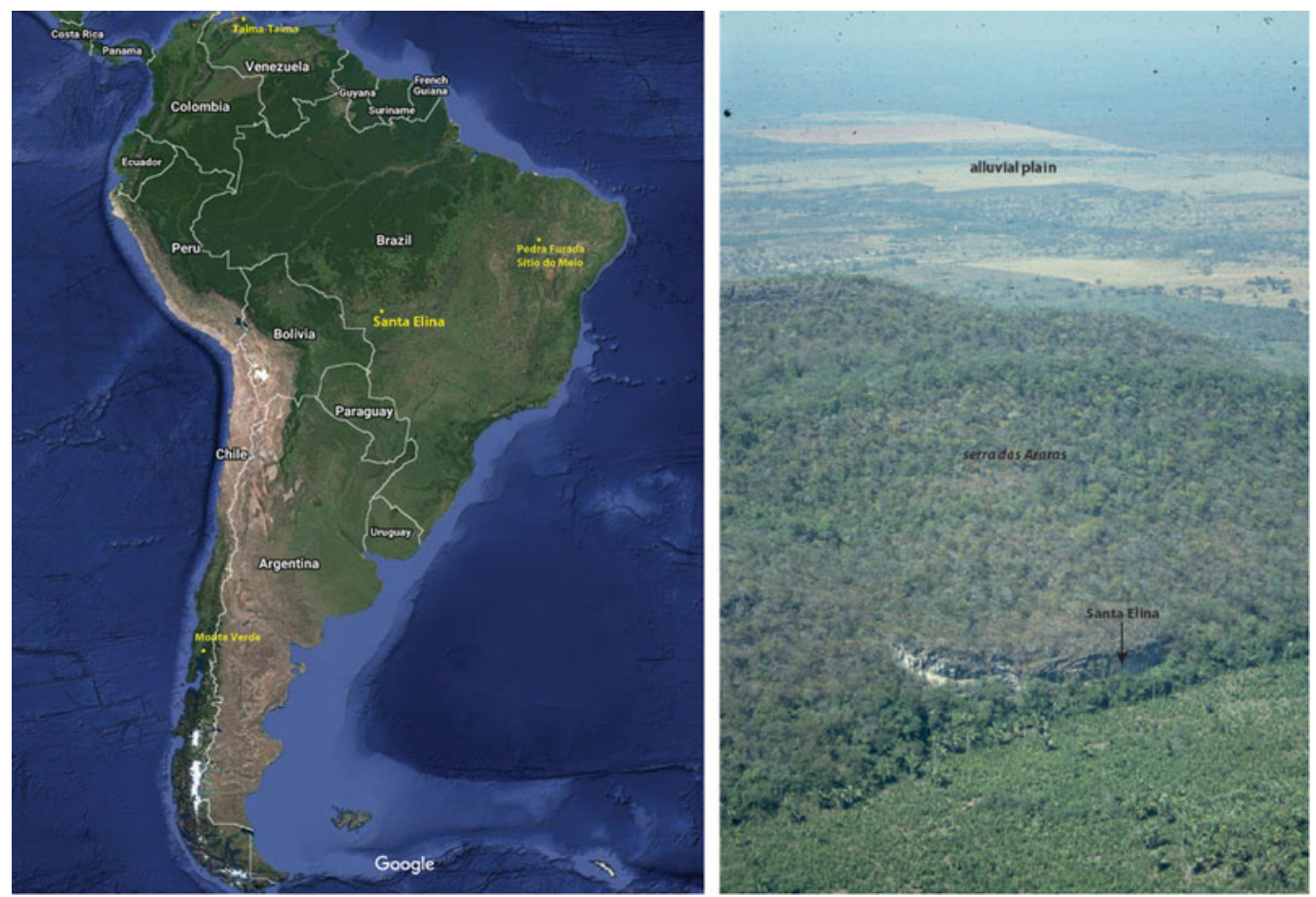

Figure 1. Left) map of South America showing some of the principal Pleistocene sites; right) the north-facing Santa Elina limestone cliff as seen from the top of the second-highest fold of the Serra mountains. Photograph by T. Aubry.

Similarly, in North America, only a handful of pre-Terminal Pleistocene sites (dating from between c. 24000 and $15000 \mathrm{BP}$ ) are known, such as Bluefish Caves (see Bourgeon et al. 2017 for the re-dating of this site), Meadowcroft and Cactus Hill, compared to a much larger number of later Palaeoindian sites (Clovis and Folsom).

The earliest settlements of North and South America appear to exhibit a wide range of technological and economic behaviours. Various lithic industries testify to the diversity of tool types; some trends persisted even following technological breakthroughs, such as the adoption of flat retouch for biface production. At the end of the Pleistocene, prehistoric peoples would have encountered various species of now extinct megafauna. Such encounters would have been less varied in North America than in South America, given the greater variety of climates and environments in the latter. Whereas the prehistoric peoples of North America mostly continued hunting cold-climate fauna (mammoth, bison, etc.), those of South America were confronted by animals that had never before been hunted by humans. Remains of giant sloth (Glossotherium) recovered from the Santa Elina shelter give an excellent example of this confrontation between hunters and a strong but probably harmless animal. The lithic assemblage at the site also, notably, lacks bifacial tools, a technological feature that persisted in central Brazilian sites during the late Pleistocene and early Holocene.

Santa Elina is geographically far removed from any other Late Pleistocene sites (Figure 1a). This raises the question of how prehistoric settlements were established in (C) Antiquity Publications Ltd, 2017 
the central region, at the confluence of the two major watersheds-the Amazon and the Cuiabá-Paraguay-Paraná.

\section{Santa Elina shelter}

The Santa Elina shelter $\left(15^{\circ} 27^{\prime} 28^{\prime \prime} \mathrm{S}, 56^{\circ} 46^{\prime} 93^{\prime \prime} \mathrm{W}, 290 \mathrm{~m}\right.$ asl $)$ is located on the southeastern side of the range that links the Serra das Araras and the Serra da Água Limpa-the mountain that rises (to $800 \mathrm{~m}$ asl) in front of the shelter-and faces the valley between the first two folds of the Serra mountains (Figure 1b). The prehistoric occupation area is 3-4m wide (between two Precambrian dolomitic limestone walls) and around $20 \mathrm{~m}$ long, with a floor that slopes slightly to the north and east. The south wall dips by about $70^{\circ}$, covering the rockshelter, which itself is $60 \mathrm{~m}$ long and lacks a ceiling. This rock wall displays almost a thousand prehistoric paintings and drawings (Vialou 2005). The north wall is an enormous parallelepiped block (Ross 2005). The top of it barely rises above later deposits forming the current ground surface. It forms a natural protection on the side facing the valley.

Excavations were conducted between 1984 and 2004 (Vilhena Vialou 2005) on two contiguous areas totalling $80 \mathrm{~m}^{2}$. Excavation of a $10 \mathrm{~m}$-long transect (Figure 2) reached a maximum depth of $3.5 \mathrm{~m}$, from which the full extent of three stratigraphic units was recorded. A test pit was dug at the base of the excavated area in squares 22-23B and $C\left(1.25 \mathrm{~m}^{2} \times 1.60 \mathrm{~m}\right.$; Figure 2$)$, reaching a depth of $5.1 \mathrm{~m}$ below the reference level.

\section{Geological and geographical background}

The Serra das Araras was formed by synclinal folds of dolomitic limestones of the Araras formation and Precambrian sandstone of the Raizama formation (Alvarenga 2005; Aubry 2005; Ross 2005). The peak altitude of the mountain range rises to $500-800 \mathrm{~m}$ above the Brazilian continental shelf, and it is $40-50 \mathrm{~km}$ wide. It is located between $14^{\circ}$ and $17^{\circ}$ south latitude and $55^{\circ}$ and $58^{\circ}$ west longitude. The Rio Cuiabá, a tributary of the Paraguay River, passes through the range approximately $30 \mathrm{~km}$ east of Santa Elina (Figure 3). On the northern side of the Serra das Araras, several palaeontological sites with extinct fauna were identified. Several archaeological occupations (including ceramics and lithics) have been discovered at open-air sites within a few kilometres of the rockshelter. No other prehistoric sites are known within $100 \mathrm{~km}$ of the site.

The geological, climatic and environmental characteristics of the Serra das Araras make for a unique landscape. Thick vegetation cover exists thanks to a variety of subsoils, whose formation was facilitated by the hydrological network of the region (Ceccantini 2005; Bachelet \& Scheel-Ybert 2017). The climatic conditions of the region are notably different from the neighbouring Cuiabá depression; the valleys offer protection from seasonal warmth and aridity. Consequently, the Serra das Araras may be regarded as a refugium of sorts, with Santa Elina offering protection from bad weather, and access to a uniquely rich environment. 


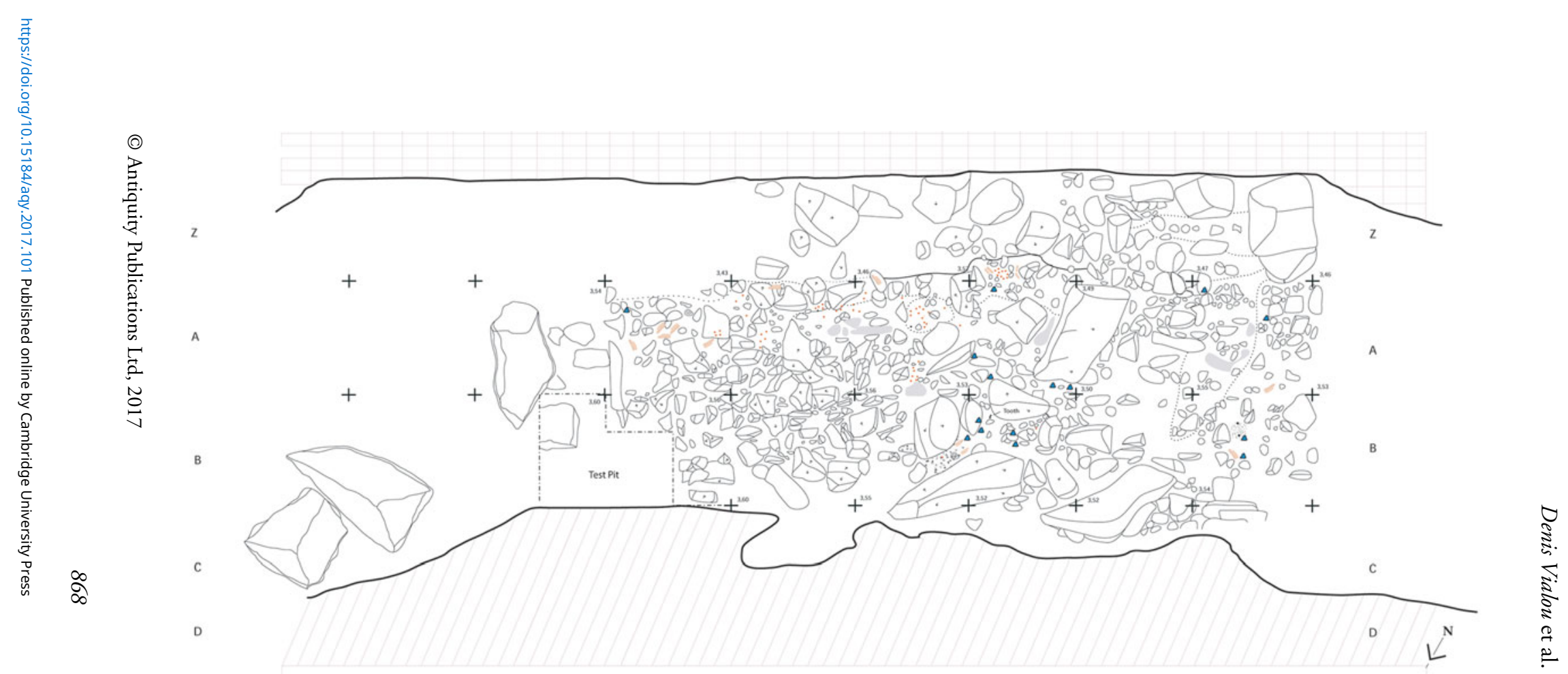

Santa Elina Unit III 4

$\begin{array}{lllllll} & \text { Legend } & \text { Stones and blocks } & \text { Osteoderms } & \text { Mollusc } \\ & - & \text { Ashes-greyish sediments } & \Delta & \text { Lithics } & & \text { Glossotherium Bones }\end{array}$

Figure 2. Plan of the final stage excavations, showing Unit III (4), the deepest-reached archaeological layer. The test pit, showing Unit IV, is located in squares 22-23B. Drawing by K. Shapazian. 


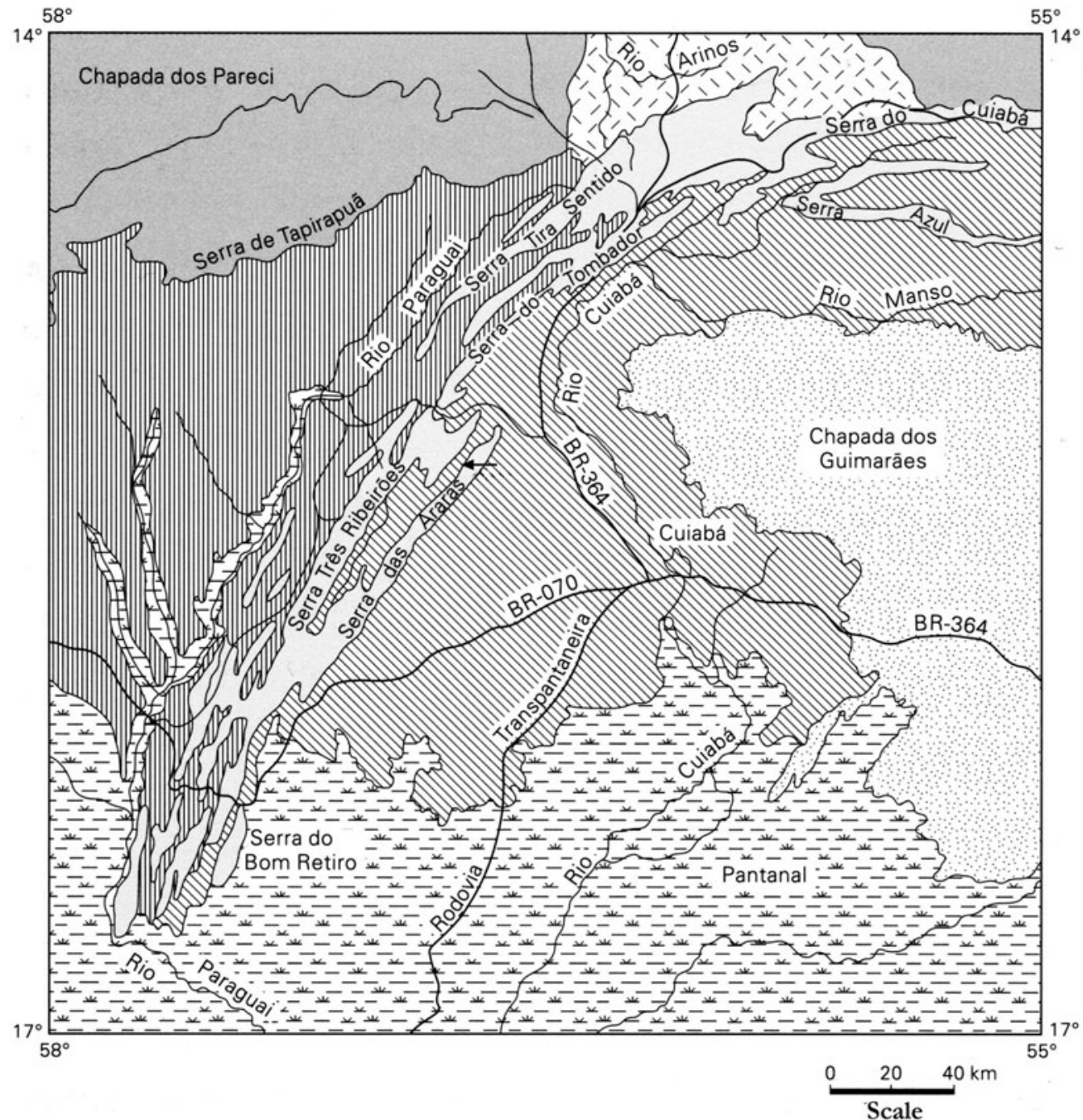

Shelf of Parana Basin

Pareci's shelf

Mountain area

Arinos peripheral depression
|III Cuiaba depression

Alto Paraguai depression

Mato Grosso Pantanal

$\leftarrow$ Localization of Santa Elina shelter

Figure 3. Geomorphological map showing the location of the Santa Elina shelter (indicated by the small black arrow) within the Serra das Araras range. Map reproduced by permission of J.L.S. Ross.

\section{Sedimentology and stratigraphy}

Deposits in the central excavation area (metres 20-29) comprised sands and limestone blocks. Sediments were undisturbed with no signs of runoff; rockfall-related disturbances 
were limited to their impact zones. The stratigraphy is clearly layered, and deposits differ according to colour and texture. Four main stratigraphic units were defined (Benabdelhadi 2005), three of which are profiled in Figure 4a.

\section{Unit IV}

Unit IV, identified only in the 22-23B test-pit, comprises a succession of slightly compacted sandy-silt layers. Grain size proportions differ from Units II and III, with $11.66 \%$ granules, $11.01 \%$ clays, $20.18 \%$ silts and $57.15 \%$ sand. The lowest strata consist of intercalated layers rich in angular limestone gravel and fragments. This could indicate a colder climatic phase. The sediments underlying Unit IV (around $4.4 \mathrm{~m}$ below the current surface) were characterised by eroded limestone blocks. Neither artefacts nor bones were found in this unit (Figure $4 \mathrm{~b})$.

\section{Unit III (4-1)}

Twenty-five square metres (Figure 2) were excavated to a depth of between 3.5 and $2.6 \mathrm{~m}$. Two stratigraphic sections were profiled, one east-west (23-25B), and one north-south (25Z-25C); Unit III is visible in its entirety in the main section of the western edge of the trench (29/30 ZABC). Generally, sediments are very sandy, although layer III (2) contains rubble (Figure $4 \mathrm{~b}$ ), and a $200-300 \mathrm{~mm}$-thick layer of rubble also separates the top of layer III (1) from layer II (3) (Figure 4a). Unit III comprises a succession of poorly sorted sandy strata, interspersed with other strata of partially compacted or loose mixed brown sands and rocky limestone slabs. Secondary illuviation processes occurred without runoff or leaching. Varying sediment characteristics and archaeological remains enabled the designation of four distinct layers.

Unit III (4) is around $400 \mathrm{~mm}$ thick, and is defined as a living floor featuring lithic artefacts and concentrations of Glossotherium bones (Figures 5 \& 6). It is composed of quite heterogeneous, compacted sediments, including gravels. Unit III (4) yielded the highest quantity of Glossotherium bones (Vilhena Vialou et al. 1995; Cartelle 2005). The osteoderms of these have been uranium-thorium dated to $27000 \pm 2000$ BP. Microscopic charcoal fragments were limited to a discrete greyish-pink ash deposit at a depth of $3.03 \mathrm{~m}$, dated by AMS to $23120 \pm 260$ BP (Gif-99177: 27 818-26887 cal BP at $95.4 \%$ probability; all radiocarbon dates were modelled in OxCal v4.3 using IntCal13 calibration curve unless specified otherwise (Bronk Ramsey 2009; Reimer et al. 2013)) by H. Valladas (2005; Table 1). Unit III (3) comprises loose brown sediments with millimetric splinters of wood. The granular texture and coarseness of the deposit shows differences with Unit III (4), which is also rich in lithic artefacts and Glossotherium bones. Unit III (2), around $300 \mathrm{~mm}$ thick, is similar to III (3), but its coarse fraction is smaller and less dense. Two wood fragments found through flotation $(2.70 \mathrm{~m} \mathrm{depth})$ were dated to approximately 26700-27 600 cal BP (Table 1). Layer III (1) is composed of coarse sands. Both of these layers contained some scattered lithic artefacts, but no faunal remains were found.

(C) Antiquity Publications Ltd, 2017 

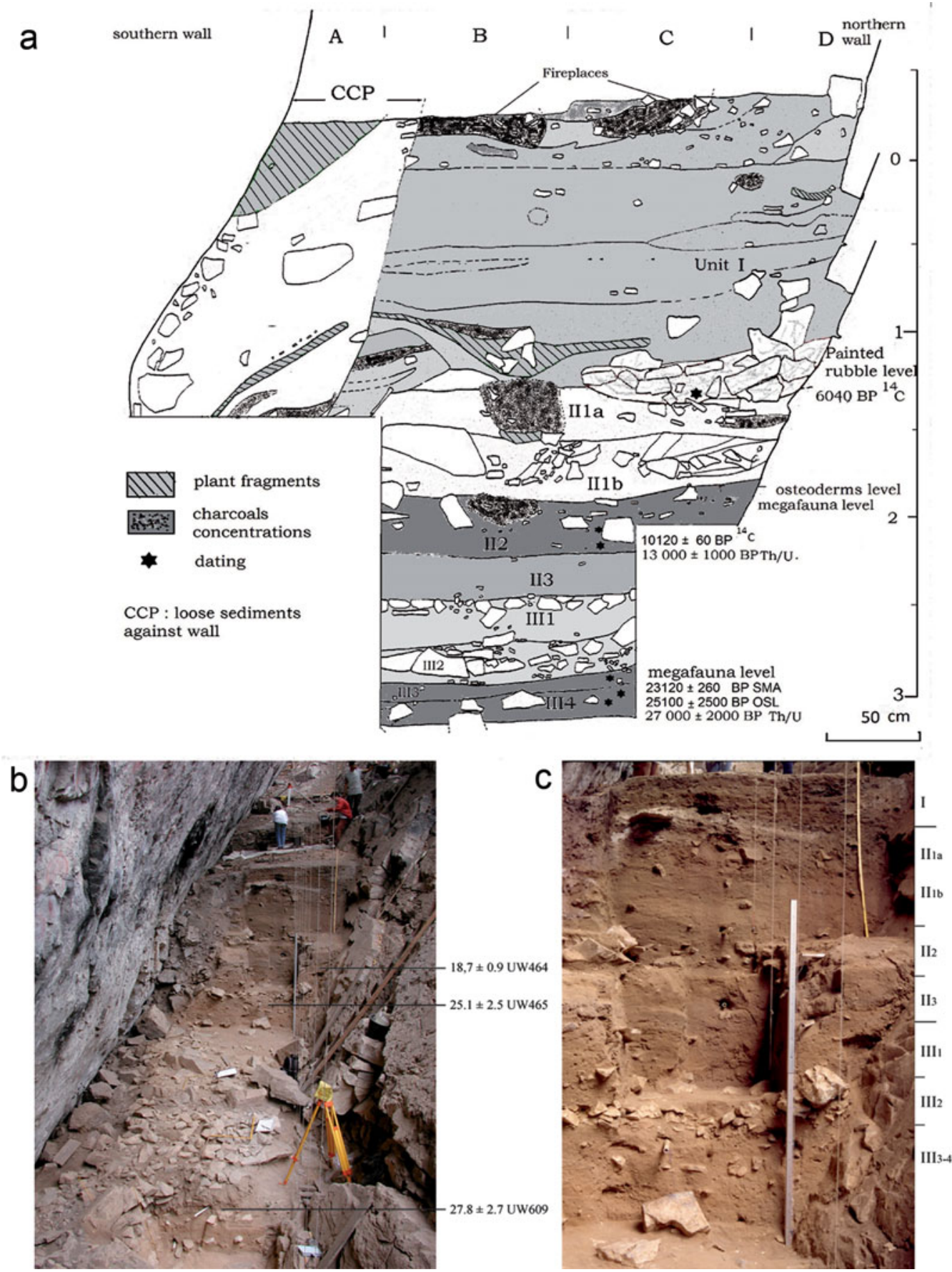

Figure 4. a) East-facing stratigraphic cross-section, surveyed by M. Benabdelhadi; b) Unit IV is visible in the foreground (squares 22-23B), with the section shown in a visible beyond. The dosimeter is situated atop III (4), $3 \mathrm{~m}$ below the reference level O; and c) a close up view of Units II and III in section. The folding metre visible in $\boldsymbol{b}$ and $\boldsymbol{c}$ is $2 \mathrm{~m}$ in length. Photographs by A. Vilhena Vialou and D. Vialou.

(C) Antiquity Publications Ltd, 2017 


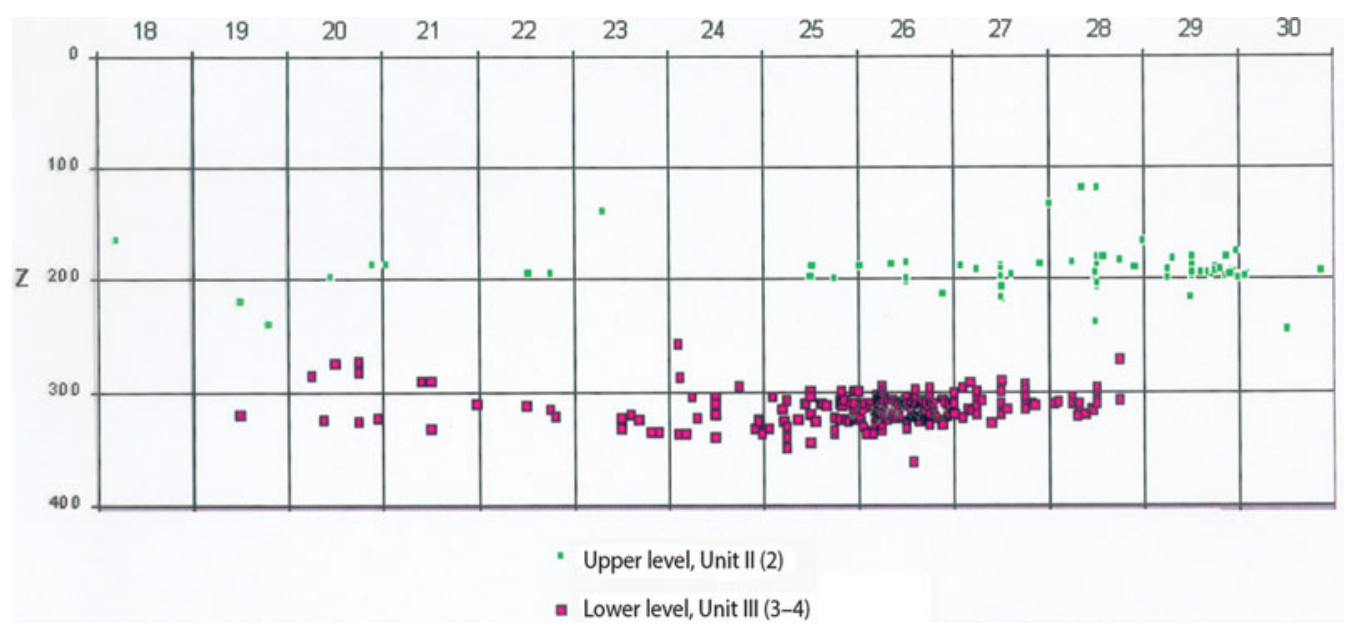

Figure 5. Plotted distribution (east to west) and depth $(\mathrm{cm})$ of Glossotherium bones recovered from Santa Elina levels III (3-4) and II (2), recorded by L. Figuti.

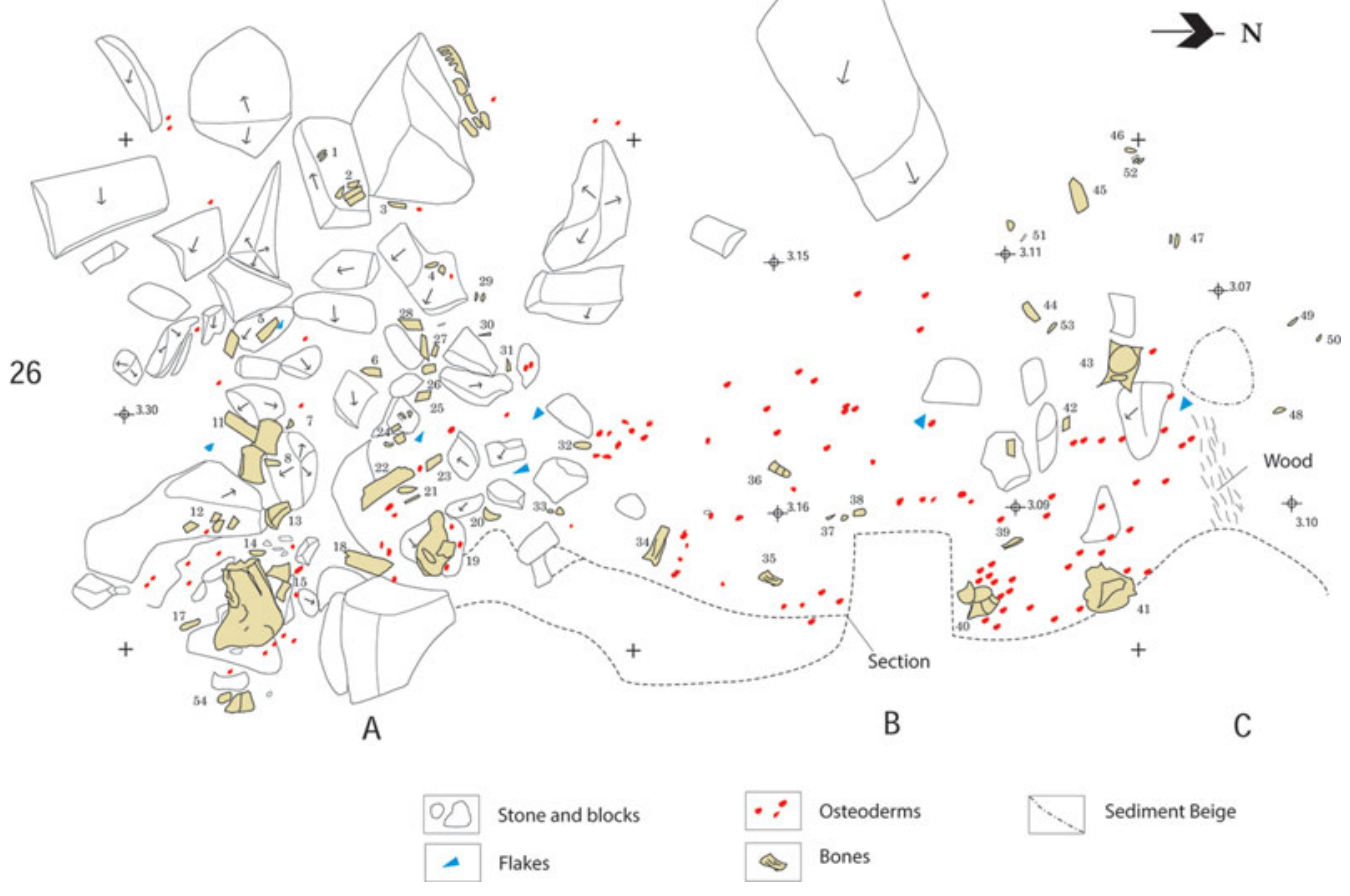

Figure 6. Survey of level III (4) showing Glossotherium bones and limestone flakes in clear spatial association with one another. Drawing by D. Vialou.

(C) Antiquity Publications Ltd, 2017 
Table 1. Santa Elina Pleistocene and Holocene main dates by three methods and laboratories $\left({ }^{14} \mathrm{C}\right.$ beta counting and AMS conventional ages: Gif/Yvette; OSL: University of Washington, 2013; U/Th: Muséum National d'Histoire Naturelle-CNRS, 1996). ${ }^{14} \mathrm{C}$ dates calibrated using OxCal v4.3 (Bronk Ramsey 2009) and the IntCal13 atmospheric curve (Reimer et al. 2013).

\begin{tabular}{|c|c|c|c|c|c|c|c|c|c|}
\hline Lab no. & Material & M & Depth & Unit & Age (conventional BP) & $\begin{array}{l}\text { Calibrated date } \\
\text { range } \mathrm{BP}(95.4 \% \\
\text { confidence })\end{array}$ & $\begin{array}{c}\text { Median } \\
\text { dates cal BP }\end{array}$ & $\begin{array}{l}\text { OSL age } \\
(\text { ky BP })\end{array}$ & $\begin{array}{c}\text { U/Th age } \\
(1 \sigma, \mathrm{ky} \mathrm{BP})\end{array}$ \\
\hline Gif-9692 & charcoal & $29 \mathrm{D}$ & 0.12 & I & $1770 \pm 60$ & $1858-1552$ & 1689 & & \\
\hline Gif-7054 & charcoal & $27 \mathrm{~B}$ & 1.10 & I & $6040 \pm 70$ & $7156-6732$ & 6893 & & \\
\hline Gif-9368 & charcoal & $27 \mathrm{C}$ & 1.87 & II (1) & $7050 \pm 55$ & 7976-7751 & 7882 & & \\
\hline Gif/LSM-10683 & charcoal & $20 \mathrm{~A}$ & 2.38 & II (2) & $9340 \pm 20$ & $10649-10500$ & 10552 & & \\
\hline Gif/LSM-11121 & charcoal & $20 \mathrm{~A}$ & 2.88 & II (2) & $9790 \pm 20$ & $11240-11195$ & 11216 & & \\
\hline Gif-8954 & charcoal & $24 \mathrm{~B}$ & 2.05 & II (2) & $10120 \pm 60$ & $12007-11404$ & 11742 & & \\
\hline Th/U SE 9404 & bone & $29 \mathrm{C}$ & 1.98 & II (2) & & & & & $13.0 \pm 1.0$ \\
\hline UW464 & quartz & $29 \mathrm{~B}$ & 2.28 & II (3) & & & & $18.7 \pm 0.9$ & \\
\hline Gif-9366 & wood & $21 \mathrm{~B}$ & 2.78 & III (2) & $22500 \pm 500$ & $27660-25896$ & 26783 & & \\
\hline Gif-9365 & wood & $22 \mathrm{~B}$ & 2.67 & III (2) & $23320 \pm 1000$ & $29924-25768$ & 27624 & & \\
\hline GIFA 99177 & microcharcoal & $27 \mathrm{~B}$ & 3.10 & III (4) & $23120 \pm 260$ & $27818-26887$ & 27402 & & \\
\hline UW465 & quartz & $28 \mathrm{~B}$ & 2.96 & III (4) & & & & $25.1 \pm 2.5$ & \\
\hline Th/U SE 9402 & bone & $26 \mathrm{C}$ & 3.10 & III (4) & & & & & $27.0 \pm 2.0$ \\
\hline UW609 & quartz & $23 \mathrm{~B}$ & 3.85 & IV & & & & $27.8-2.7$ & \\
\hline
\end{tabular}

\section{Research}


Unit II (1a;1b;2\&3)

Unit II (Figures 4 \& 5) consists of four thick, homogeneous layers (Figure 4a) between 2.50 and $1.40 \mathrm{~m}$ deep, and covering $30 \mathrm{~m}^{2}$. There is an alternation of subhorizontal sandy sediments and levels comprising limestone blocks and rubble. The proportion of granules (14\%) and poorly sorted sands (48.02\%) is smaller than in Unit III (granules 20.18\%, and rough textured sands $54.78 \%$ ), with coarse sands being more dominant. Silts represent $19.12 \%$, and the clays $4.92 \%$. The lowest layer, Unit II (3), is rich in nodules of illuvium clays. Unit II (2) comprises fine sands, and is rich in Glossotherium bones (Figure 5) and associated lithic artefacts. Some of the Glossotherium bones, including a clavicle and a big thoracic vertebra, are calcified. An episode of strong humidity, dated to $10120 \pm 60 \mathrm{BP}$ (Gif8954: $12007-11404 \mathrm{cal} \mathrm{BP}$ at $95.4 \%$ probability), is represented by a $50-100 \mathrm{~mm}$-thick calcitic floor, which overlies numerous blocks and stones in the area of $20-24 \times \mathrm{B}-\mathrm{C}$, at a depth of around $2 \mathrm{~m}$. The flows that resulted from this humidity created gour (rimstone) speleothems that have indurated the ground.

A rock of greater size than $1 \mathrm{~m}^{3}$, found in $23 \mathrm{Z}-\mathrm{B}$ along with other fallen blocks overlying Unit II (1), attests to a phase of rockfall that happened during the first half of sediment deposition, causing some localised stratigraphical disturbances. Units II (1a) and II (1b) are characterised by a coarse and loose sandy matrix. Their sedimentological nature lacks any similarity to the deposit of Unit I.

\section{Unit I}

Unit I was visible throughout the totality of the excavated area, extending from the surface down to a depth of $1.40 \mathrm{~m}$. Covering the same central area is a dry, fine, powdery sediment without any pedogenesis. Unit I is clearly anthropogenic, as seen from hearths with high quantities of large charcoal fragments; several deposits of ash; stone arrangements; macrofossils of edible (palmer fruits) and processed vegetal matter; and a rudimentary lithic industry. The proportion of granules is reduced $(<10 \%)$, increasing towards the top. Sands are coarse for the most part, and dominate the silts (19\%) and clays (10.38\%), the clays being denser than in Units II and III.

Stratified deposits in the central, protected area of the shelter show evidence of natural disturbances that have been clearly delineated during excavations: these are mostly rockfalls, a narrow detachment of eroded deposits against the high wall inside the shelter (marked as CCP in Figure 4A). These spatially confined secondary phenomena had no effect on the formation of the subhorizontal, stratified colluvium. The three units that incorporate a sequence of human occupations (I, II and III) are clearly distinct. The record of in situ sedimentary dynamics allows confidence in the integrity of the anthropic sequence and its dated chronology.

\section{Archaeology}

Archaeological evidence at Santa Elina relates to successive occupations during the Pleistocene, the Pleistocene-Holocene transition and the middle Holocene.

(C) Antiquity Publications Ltd, 2017 


\section{Pleistocene: Unit III and Unit II (3)}

Unit III (4) \& (3): around 200 Glossotherium bones and some 300 lithic artefacts were gathered within an area of about $12 \mathrm{~m}^{2}(23-28 \times \mathrm{A}-\mathrm{C})$. Across $25-27 \times \mathrm{A}-\mathrm{B}$, bones and lithics were found in close spatial association with one another. A few bone fragments and osteoderms were discovered outside of this area, and a small displacement of material close to the wall with various broken bones was found throughout $23-27 \mathrm{~A}$, with a high concentration of limestone rubble. The bones belong to the anterior quarters of a young Glossotherium aff. G. lettsomi (L. Figuti and M.F. Pacheco pers. comm.). Among them are two fragmented mandibles, fragments of cranial bones including a molar (M1), four vertebrae (including two articulated together), and several thousand osteoderms, some of which are plotted in Figure 6. All of the bones had had their periosteum biochemically altered, making it impossible to observe cut-marks or other human interventions. No systematic

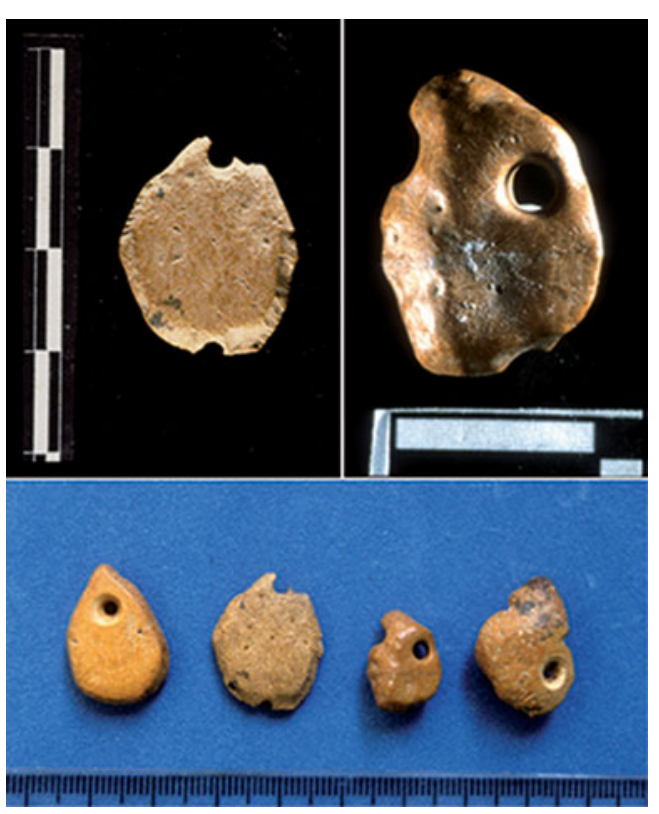

Figure 7. Two archaeological osteoderm ornaments from Unit III (top left) and layer III (4) (top right). Bottom: the original ornaments in the centre are flanked by two experimentally reconstructed versions. Photographs by $A$. Vilhena Vialou and D. Vialou. fracture pattern was observed and bone collagen was lacking. The osteoderms formed either a layer (carpet) or a packed accumulation. In some cases, a discrete but significant arrangement characterises the interventions on skeletal elements, perhaps where skin was cut. Additionally, a concentration of 49 osteoderms over an area of $100 \times 100 \mathrm{~mm}(c .100 \mathrm{~mm}$ deep$)$, was probably deposited intentionally. Some of these osteoderms were broken after firing.

Two modified osteoderms (Figure 7 top), probably ornaments, hint at the dynamic relationship between hunter and animal (Vilhena Vialou 2003, 2011). The first was found in association with 60 bone flakes and various lithic artefacts, mainly made of limestone. The osteoderm has a perforation at each end of its longitudinal axis. It was also abraded more intensely on one side than the other. The specimen is incomplete due to taphonomic fracturing and rodent gnawing (Vilhena Vialou 1997-1998). The second ornament was recovered from the same context and was well preserved. It is perforated near one end, and bevelled by heavy abrasion on both faces. This technological assessment was supported by experimentation using various abrading and drilling tools (Figure 7 bottom).

The lithic industry comprised approximately 330 pieces, mostly limestone flakes, of which 100 were peripherally retouched. There were also 70 retouched cores (cases of abrupt retouch are regular and continuous) of limestone and some flint and quartz debitage, 

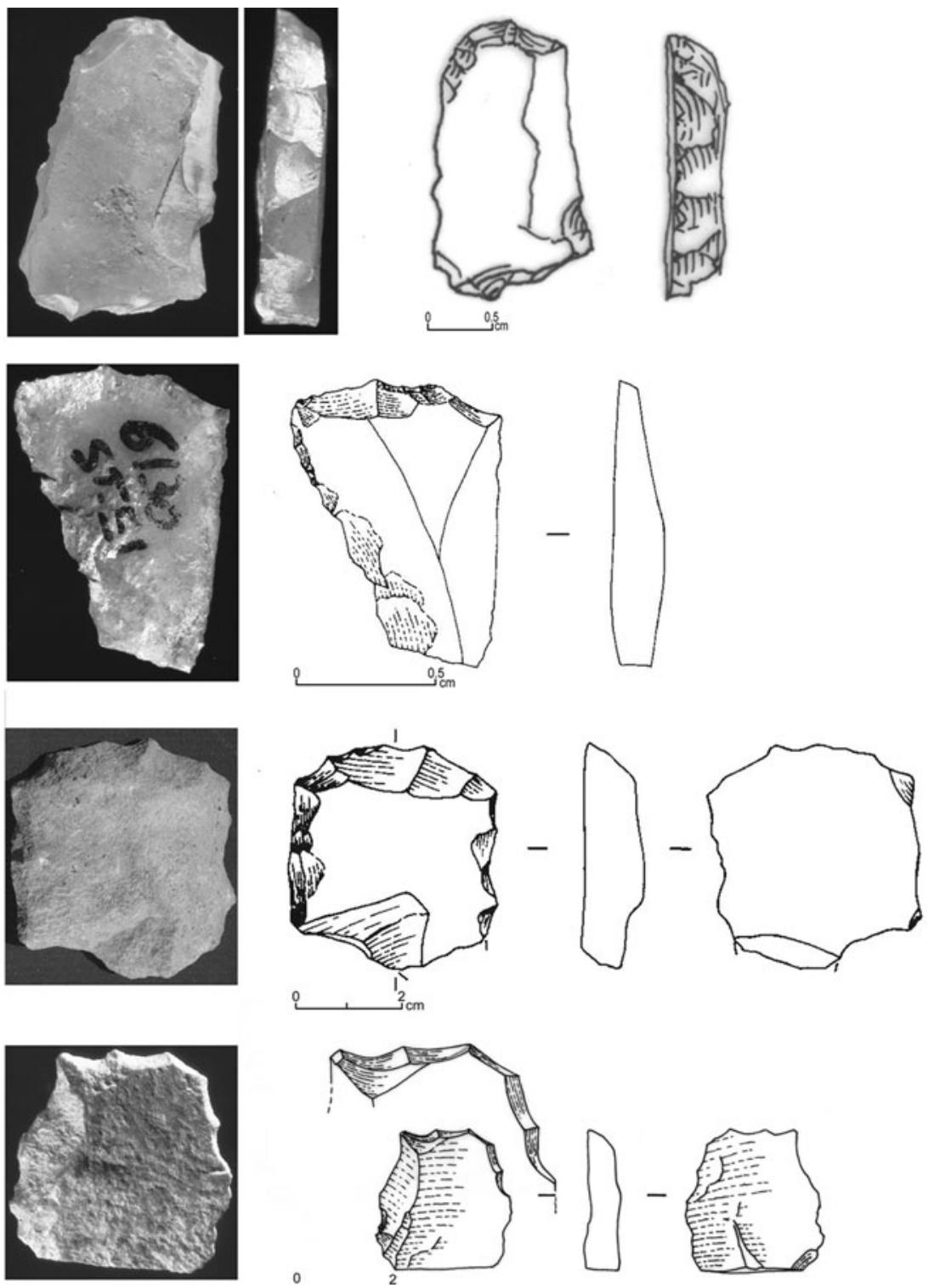

Figure 8. Lithics from Unit III (3) and (4). From top to bottom: two retouched siliceous microblade cores, one retouched limestone microblade core, and one limestone flake showing a drill-like micro-peak. Photographs by J.-P. Kauffmann, A. Vilhena Vialou and D. Vialou. Drawings by L. Chiotti.

and there is a microlithic industry evidenced by three small, well-worked siliceous blade cores with retouched edges. Several limestone microblade cores $(20 \mathrm{~mm})$ with cortical butts exhibit evidence of retouch with denticulate edges (Figure 8). The robust, notched or denticulated tools (Figure 9) contrast with the smaller flakes. Evidence of microwear, such as polishing on the cutting edges, is visible on some artefacts.

The raw lithic materials used are exogenous to the shelter, with some coming from sources as far as $2 \mathrm{~km}$ away. Limestone came from outcrops located about $50 \mathrm{~m}$ below the (C) Antiquity Publications Ltd, 2017 

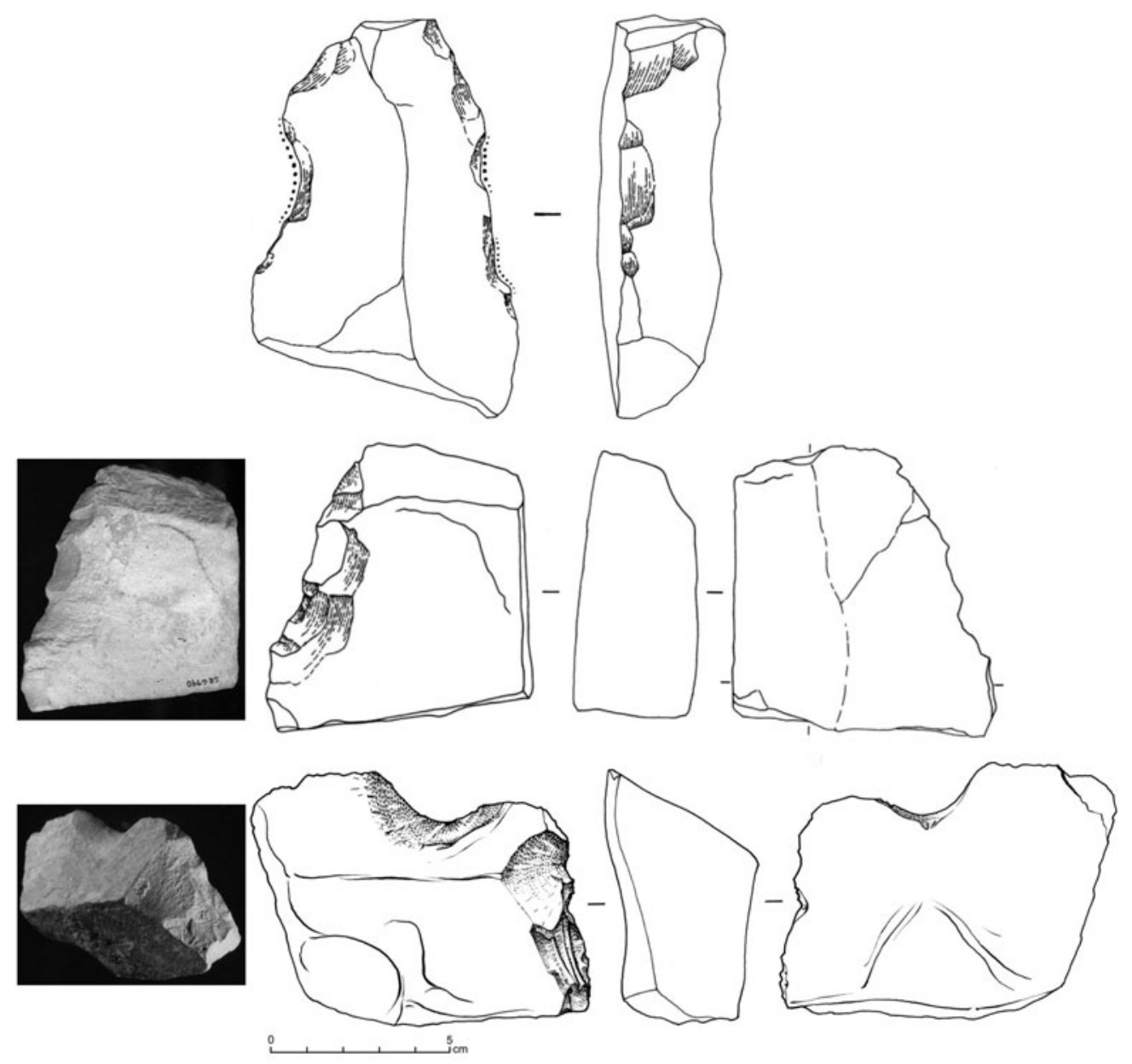

Figure 9. Large, thick retouched limestone flakes with partially notched and denticulated edges recovered from layer III (4). The notches and denticulates were made using semi-abrupt retouch. Photographs by J.-P. Kauffmann, A. Vilhena Vialou and D. Vialou. Drawings by L. Chiotti.

shelter. The limestone is fine-grained and includes detrital quartz grains, differing from the limestone walls, blocks and rubble of the shelter. Flint nodules and a few quartz crystals were procured via a rift passage giving access to the Serra Valley, while a dozen small, flat haematite pieces were sourced from the thalweg of the Rio Cuiabá.

Unit III (2), III (1) \& II (3): these layers separate two discrete horizons of several thousand Glossotherium bones (many of which are osteoderms) in Unit III (3 \& 4) and Unit II (2) (Figuti 2005). Two series of dates also bracket these levels (Table 1), emphasising the fundamental stratigraphic and chronological division between the Pleistocene and Holocene occupations (Figure 5). Sediments of coarse sands include a level of limestone blocks at a depth of $2.60 \mathrm{~m}$, which yielded 60 limestone fragments and flakes (some with retouch) and no Glossotherium bones. These lithic artefacts do not constitute an 
archaeological layer; they were randomly dispersed via slope dynamics, probably the result of various climatic events during the Pleistocene, into the western half of the shelter.

\section{Pleistocene to Holocene transition}

Unit II (2): this layer is mainly characterised by sets of osteoderms scattered over an area of $10 \mathrm{~m}^{2}$, and other Glossotherium bones, including a scapula, a thoracic vertebra, a tarsus, a lower molar (M2), and several bits of long bones and other fragments. Most of the bones came from an elderly individual. Hundreds of osteoderms were found in the western stratigraphic section between a depth of 1.80 and $2.00 \mathrm{~m}$. Several occupations were delimited in squares $20 \mathrm{~A}-24 \mathrm{~A}$ between a depth of 2.28 and $2.88 \mathrm{~m}$. They include a

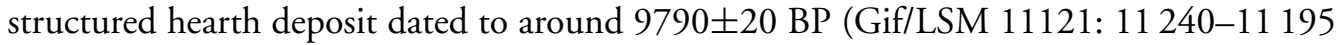
cal BP at $95.4 \%$ probability; Table 1), and a succession of other fireplaces, surrounded by stones or blocks $(300 \times 200 \times 150 \mathrm{~mm})$. Some of these were coloured with red pigments made with haematites. In the same area, there were small animal bones, mostly of rodents, but also frogs, birds and fish. Eighteen per cent of these bones show signs of burning, and 20 per cent of the numerous molluscs recovered were also calcinated, showing an obvious link with the fireplaces (Pacheco 2009). The lithic industry (Vilhena Vialou 2005, 2007) is represented by approximately 1000 pieces. The reliance on local sourcing for hard and dense lithic materials suggests efficient procurement strategies, as also inferred for the occupants of the shelter during Unit III (4). The debitage of limestone fragments, however, is much more widespread than in III (4). Small, short and thin flakes are numerous, and in the case of limestone, flint or sandstone pieces (which were also sourced from the valley floor), are partly retouched. Among these, some refitting flakes were found. The raw materials used in the surrounding valley are more diverse (flint and sandstone) than in Unit III (4), and were collected both inside and outside the shelter. One hundred haematite fragments were also found, many of which bear evidence of abrasion, probably from having been used to create powder.

\section{Holocene}

Unit II ( $1 a$ \& $1 b)$ : yielded a lithic industry containing a dozen exceptional, elaborately shaped, unifacial tools, made from excellent-quality flint, sandstone and limestone.

Unit I: dated to between 7000 and 1500 cal BP, Unit I contains hearth places, stone arrangements, edible and processed vegetal matter, and a rudimentary lithic industry, comprising limestone, flint and sandstone debitage. The virtual absence of ceramics at the top of the sequence suggests that Santa Elina was neither associated with pottery production nor located on the routes used by the pottery-using peoples of the central Planalto. Many haematite sticks, probably used as a colouring agent, were also found. A pavement of almost 400 rubble stones, spotted with red pigment, was dated to around $7000 \mathrm{cal}$ BP (Gif-7054; Table 1). The majority of this sequence is probably contemporaneous with wall paintings (animals, human figures of diverse styles and many geometrical signs) in the shelter. All of these representations are well distinguished by their style and theme (Vialou 2005).

(C) Antiquity Publications Ltd, 2017 


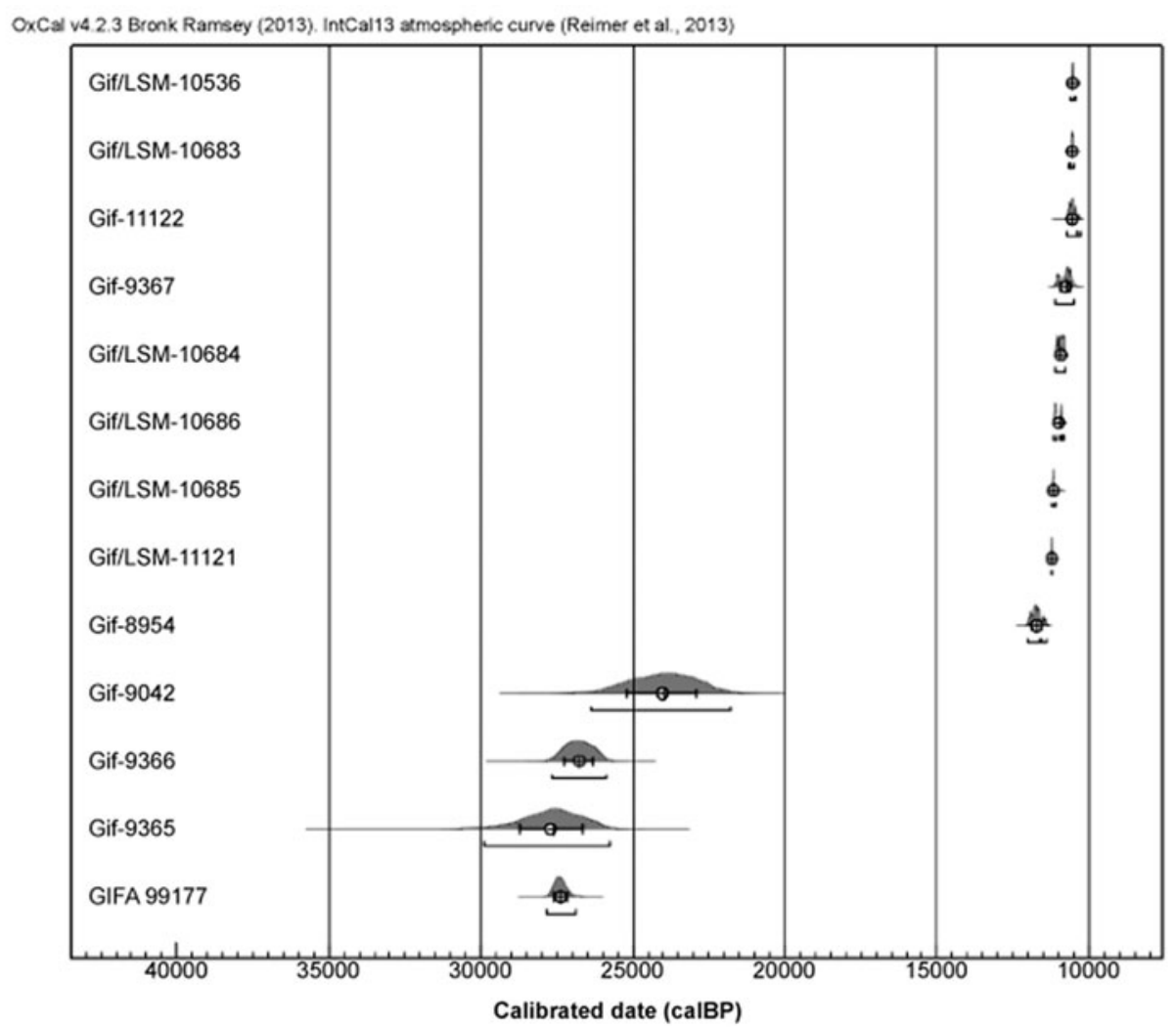

Figure 10. Calibrated radiocarbon dates from Santa Elina by M. Fontugne. Dates calibrated using OxCal v4.3 (Bronk Ramsey 2009) and the IntCal13 atmospheric curve (Reimer et al. 2013). Around 60 dates have been taken from the site. The main dates connected with the upper and lower limits for the stratigraphic units are given in Table 1.

\section{Chronology}

Three methods of absolute dating were used in Santa Elina: radiocarbon dating — both beta counting (Fontugne et al. 2005) and AMS (Valladas 2005) —uranium-thorium (U/Th) (Falguères 2005) and optically stimulated luminescence (OSL) (Feathers 2005). Results are summarised in Table 1 and Figure 10.

\section{Dating archaeological deposits}

AMS dating was only used for Unit III (4), the results of which are summarised in the sedimentology and stratigraphy section. Microcharcoals from a thin, ashy layer were dated to $23120 \pm 260$ BP (GIFA-99177: $27818-26887$ cal BP at $95.4 \%$ probability; Figure 10). This overlapped with dates obtained from driftwood, and also the U/Th dating of Glossotherium remains from two anthropic occupations (III (3-4) and II (2)).

Beta counting conventional radiocarbon dating was applied to samples from three stratigraphic units (III, II and I): 
1) Unit III (2): immediately above Unit III (3) and the older human occupation of Unit III (4), in squares 21-22B, two pieces of naturally saturated wood (species undetermined) from a waterlogged deposit were dated to 23320 1000 BP (Gif-9365: 27 818-26887

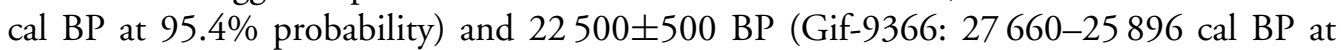
95.4\% probability; Figure 10). The taphonomic alteration through saturation explains the amplitude of the two-sigma range, but despite the relative imprecision, these two dates were essential for securing the chronology of the archaeological sequence in the early stages of the excavation. These pieces are stratigraphically lower than the occupation (Unit II (2) dated to around $11000 \mathrm{BP}$; Table 1), which includes the association of human remains and the apparently structured distribution of megafauna remains; they are just above the oldest human occupation in Unit III (4).

2) Unit II (2): charcoals associated with Glossotherium remains gave a date of $10120 \pm 60$ BP (Gif-8954: 12 007-11404 cal BP at 95.4\% probability). Charcoals collected from the hearths and elsewhere in II (2) support a reduced time span, with seven ${ }^{14} \mathrm{C}$ dates in 20-21A ranging between 9340 20 BP (Gif-10683: 10649-10500 cal BP at 95.4\% probability) and $9790 \pm 20 \mathrm{BP}$ (Gif-11121: $11240-11195 \mathrm{cal} \mathrm{BP}$ at $95.4 \%$ probability; Table 1, Figure 10).

3) Unit II (1): seven dates from middle Holocene deposits span the period 9000-7000 BP. One of them, 7050 \pm 55 BP (Gif 9368: 7976-7751 cal BP at 95.4\% probability), gives the most recent date for Unit II (1), corresponding with the limit between the typical sandy sediments of Unit II and the powdery sediments of Unit I. The lithic industry comprised just a few pieces, but of different raw materials and with some retouched pieces similar to the unifacial tools found in central Brazil. Five dates from middle Holocene deposits span the period 8955 (Gif-9039) to 7382 BP (Gif-9041).

4) Unit I: 28 radiocarbon dates from stratigraphic Unit I provide a very precise and detailed chronology for a series of uninterrupted and well-stratified occupations, with a youngest terminal occupation date of $1770 \pm 60 \mathrm{BP}$ (Gif-9692: 1858-1552 cal BP at $95.4 \%$ probability)—only dates regarded as notable upper and lower limits for various stratigraphic units are included in Table 1. The pavement with coloured blocks was dated to $6040 \pm 70$ BP (Gif-7156: 7011-6732 cal BP at 95.4\% probability).

\section{U/Th dating applied to osteoderms from Units III and II}

Unit III (4): osteoderms collected from a depth of $3 \mathrm{~m}$ in 26C were dated to $31000 \mathrm{BP}$ (Vilhena Vialou et al. 1995), which after refinement (to account for the exogenous thorium content of the samples) was adjusted to $27000 \pm 2000 \mathrm{BP}$ (U/Th SE 9402 within $1 \sigma$ ). Unit II (2) (1.98m deep) has one date derived from osteoderms found within the section wall of the central excavated area 29C: $13000 \pm 1000 \mathrm{BP}$ (U/Th SE 9404 within $1 \sigma$ ). These dates, obtained despite the comparably low uranium content $(0.25-0.30 \mathrm{ppm})$ of the osteoderms, are fully equivalent with each other. The two results align favourably with the radiocarbon dating, particularly the date of $10120 \pm 60 \mathrm{BP}$ (Gif-8954) obtained from the fireplace with associated fauna excavated in square $24 \mathrm{~B}$, at a depth of $2.05 \mathrm{~m}$. The chronometric accordance between radiocarbon and U/Th dates is spread over several millennia, but within

(C) Antiquity Publications Ltd, 2017 
reasonable statistical approximations, i.e. stratigraphically visible hiatuses in deposition correspond well with the radiocarbon and U/Th chronologies.

\section{OSL dating of sedimentological data}

OSL was applied to Units IV, III and II. An equivalent dose was determined using the single aliquot regenerative dose (SAR) method on single grains (Murray \& Wintle 2000).

The most ancient of these dates, obtained from the test pit sunk into Unit IV, was $35500 \pm 2400 \mathrm{BP}$ (Feathers 2005). After recent methodological revision, this date has been refined to $27800 \pm 2700 \mathrm{BP}$ (UW 609). Quartz grains from Unit III (4), located between $2.96 \mathrm{~m}$ and $3 \mathrm{~m}$ deep, in the same east-facing section where the U/Th dates of osteoderms were taken, were dated at $25100 \pm 2500$ (UW 465) and $22500 \pm 1500$ (UW 462). The age of Unit II (3) was determined to be around $18700 \pm 900$ (UW 464).

\section{South American settlements in the late Pleistocene and early Holocene}

The successful adaptation of prehistoric societies to environmental and climatic changes between 15000 and 9000 BP is indicated by the high density of sites in some habitats (Gruhn \& Bryan 2011; Bueno et al. 2013; Dillehay 2013). In various different biomes and geographic landscapes, fluctuations in humidity and occasional drought spells were documented. The final cold fluctuations of the Last Glacial Maximum were particularly strong in the Andes (as evidenced at Pikimachay) and the Southern Cone (e.g. as shown at Cueva Fell and Los Toldos). In the north of the subcontinent, near the Atlantic coast of the Caribbean, the Venezuelan site of Taima-Taima was made famous by the discovery of a juvenile mastodon pelvis, pierced by a bifacial, lanceolate projectile point of 'El Jobo' type. A jasper flake with evidence of use-wear was found in association. The mastodon pelvis was recovered from an occupation reliably radiocarbon-dated to between $13390 \pm 130$ and $12580 \pm 150$ BP (Gruhn \& Bryan 1989).

Of the several hundred prehistoric occupations known and reliably dated to the Pleistocene throughout the Americas, less than two dozen are known from before the final millennia of this period. This may reflect a real contrast in the density of sites between phases of initial colonisation and subsequent settlement expansion; it may equally result, however, from a relative lack of fieldwork, from methodological inadequacies among older excavations, and from difficulties in absolute dating.

At present, the isolated open-air settlement of Monte Verde in Chile (Dillehay \& Collins 1988; Dillehay 1997) is the oldest known and most widely accepted site in south-west South America. Its location fits the Pacific coastal migration route hypothesis proposed for the early peopling of the Americas (Meltzer 2009). In this respect, the geographic location of Monte Verde is completely different from Santa Elina. Monte Verde demonstrates that the peopling of the Andes occurred before the end of the Pleistocene (Lavallée 2000), and that, consequently, a route penetrating through the mountains cannot be excluded.

The Pleistocene antiquity suggested for the Pedra Furada region (Piauí, Brazil) remains plausible, as shown by recent excavations (Boëda et al. 2013) of sites located on different, 
nearby geological outcrops. At these sites, including Vale da Pedra Furada (located on a sandstone hill), Tira Peia (within a limestone formation) (Lahaye et al. 2013) and especially Sitio do Meio (within a sandstone formation), several archaeological layers with hundreds of well-identified tools were found. These layers had clear topographic and stratigraphic correlations with radiocarbon-dated charcoals and OSL-dated sediments.

The establishment of Pleistocene prehistory in South America is furthered substantially by work at Santa Elina and other sites that offer new perspectives on the early settlement of the New World. Isolated sites, such as Santa Elina, Monte Verde, the Piauí sites and TaimaTaima, are geographically removed from one another, and have accordingly independent chronological and cultural histories. Furthermore, it is clear that the variety of very ancient habitats found across this extensive geographic area renders it impossible to create a generalised impression of the earliest peopling of the subcontinent.

The crucial significance of Santa Elina for understanding the earliest period of known prehistoric settlement in South America lies in the close articulation of archaeological, palaeontological, sedimentological and chronological datasets from the site. Human presence is attested by: a) lithic materials manufactured on site with evidence of debitage and retouch; b) the bones of extinct megafauna (Glossotherium), partly brought into the shelter, and clearly associated with the lithics; and c) by hearth deposits identified throughout the sequence. The results from three complementary dating methods $-{ }^{14} \mathrm{C}$, OSL (sediments) and U/Th (Glossotherium bones) —are in relative agreement with one another, and confirm the stratigraphic integrity of the depositional history at Santa Elina. The dates indicate two periods of human occupation, with a date of $23120 \pm 260 \mathrm{BP}$ for the first, and a date of $10120 \pm 60 \mathrm{BP}$ for the beginning of the second (Table 1). These dates confirm the association between archaeological artefacts and Glossotherium bones. Subsequent occupations terminated around 2000 BP. The Pleistocene archaeology of the Santa Elina shelter gives a unique example of the exploitation of the giant sloth in Brazil, and boasts a series of artefacts that testify to a developed lithic technology from the site's earliest occupation, making it an intriguing piece of the jigsaw in tracing the earliest settlers of South America.

\section{Acknowledgements}

Our thanks go to the Ministère des Affaires Etrangères (France) for funding, and the Museu de Arqueologia e Etnologia da Universidade de São Paulo (Brazil) and the Muséum National d'Histoire Naturelle-CNRS (France) for their constant logistical support. Our deepest gratitude is extended to the Botelho Campos family, the owners of Fazenda Santa Elina, for their permission and their constant and generous reception. We also thank all of the researchers who have contributed to the excavations and analysis. Kind thanks finally to Vincent Vialou, Karin Shapazian, Jean-Jacques Bahain and Eric Robert for their assistance in the preparation of this article.

\section{References}

Alvarenga, C.J. DE S. 2005. Contexto geológico da Serra das Araras, in A. Vilhena Vialou (ed.) Pré-história do Mato Grosso: Santa Elina: 85-86. São Paulo: Editora da Universidade de São Paulo.

Aubry, T. 2005. Litologia e aproveitamento das rochas, in A. Vilhena Vialou (ed.) Pré-história do Mato Grosso: Santa Elina: 107-12. São Paulo: Editora da Universidade de São Paulo.
Bachelet, C. \& R. Scheel-Ybert. 2017. Landscape and firewood selection in the Santa Elina rock shelter (Mato Grosso, Brazil) during the Holocene. Quaternary International 431: 52-60. https://doi.org/10.1016/j.quaint.2015.12.019

(C) Antiquity Publications Ltd, 2017 


\section{Peopling South America's centre: the late Pleistocene site of Santa Elina}

Benabdelhadi, M. 2005. Contribuição da sedimentologia e da microscopia para o conhecimento dos sítios pré-históricos: métodos de pesquisa e resultados, in A. Vilhena Vialou (ed.) Pré-história do Mato Grosso: Santa Elina: 113-24. São Paulo: Editora da Universidade de São Paulo.

Boëda, E., A. Lourdeau, C. Lahaye, G.D. Felice, S. Viana, I. Clemente-Conte, M. Pino, M. Fontugne, S. Hoeltz, N. Guidon, A.-M. Pessis, A. Da Costa \& M. Pagli. 2013. The Late Pleistocene industries of Piauí, Brazil: new data, in K.E. Graf, C.V. Ketron \& M.R. Waters (ed.) Paleoamerican odyssey: 445-65. College Station: Center for the Study of the First Americans, Texas A\&M University.

Bourgeon, L., A. Burke \& T. Higham. 2017. Earliest human presence in North America dated to the Last Glacial Maximum: new radiocarbon dates from Bluefish Caves, Canada. PLoS ONE 12: e0169486. https://doi.org/10.1371/journal.pone.0169486.

Bronk Ramsey, C. 2009. Bayesian analysis of radiocarbon dates. Radiocarbon 51: 337-60. https://doi.org/10.2458/azu_js_rc.51.3494

Bueno, L., A.S. Dias \& J. Steele. 2013. The Late Pleistocene/Early Holocene archaeological record in Brazil: a geo-referenced database. Quaternary International 301: 74-93. https://doi.org/10.1016/j.quaint.2013.03.042

Cartelle, C. 2005. A Preguiça-terrícola de Santa Elina, in A. Vilhena Vialou (ed.) Pré-história do Mato Grosso: Santa Elina: 159-62. São Paulo: Editora da Universidade de São Paulo.

Ceccantini, G.C.T. 2005. A cobertura vegetal associada ao abrigo rupestre, in A. Vilhena Vialou (ed.) Pré-história do Mato Grosso: Santa Elina: 125-38. São Paulo: Editora da Universidade de São Paulo.

Dillehay, T.D. 1997. Monte Verde: a Late Pleistocene settlement in Chile. Volume 2, the archaeological context and interpretation. Washington, D.C. Smithsonian Institution Press.

- 2013. Entangled knowledge: olds trends and new thoughts in first South American studies, in K.E. Graf, C.V. Ketron \& M.R. Waters (ed.) Paleoamerican odyssey: 377-96. College Station: Center for the Study of the First Americans, Texas A\&M University.

Dillehay, T.D. \& M. Collins. 1988. Early cultural evidence from Monte Verde in Chile. Nature 332: 150-52. https://doi.org/10.1038/332150a0

FALGuères, C. 2005. O método por urânio-tório (U-Th), in A. Vilhena Vialou (ed.) Pré-história do Mato Grosso: Santa Elina: 49-54. São Paulo: Editora da Universidade de São Paulo.

FeAthers, J. 2005. Datação por luminescência óptica estimulada, in A. Vilhena Vialou (ed.) Pré-história do Mato Grosso: Santa Elina: 55-59. São Paulo: Editora da Universidade de São Paulo.
Figuti, L. 2005. Consideraçôes sobre a distribuição da megafauna em Santa Elina, in A. Vilhena Vialou (ed.) Pré-história do Mato Grosso: Santa Elina: 163-66. São Paulo: Editora da Universidade de São Paulo.

Fontugne, M., C. Hatté \& C. Noury. 2005. Quadro cronológico, in A. Vilhena Vialou (ed.) Pré-história do Mato Grosso: Santa Elina: 103-106. São Paulo: Editora da Universidade de São Paulo.

Gruhn, R. \& A.L. Bryan. 1989. The record of Pleistocene megafaunal extinction at Taima-Taima, northern Venezuela, in P.S. Martin \& R.G. Klein (ed.) Quaternary extinctions: a prehistory revolution: 128-37. Tucson: University of Arizona Press.

- 2011. A current view of the initial peopling of the Americas, in D. Vialou (ed.) Peuplements et préhistoire en Amériques: 17-30. Paris: CTHS.

Lahaye, C., M. Hernandez, E. Bö̈da, G.D. Felice, N. Guidon, S. Hoeltz, A. Lourdeau, M. Pagli, A.-M. Pessis, M. Rasse \& S. Viana. 2013. Human occupation in South America by 20,000 BC: the Toca da Tira Peia site, Piauí, Brazil. Journal of Archaeological Science 40: 2840-47. https://doi.org/10.1016/j.jas.2013.02.019

LavalléE, D. 2000. The first South Americans. Salt Lake City: University of Utah.

Meltzer, D.J. 2009. First peoples in a new world. Colonizing Ice Age America. Berkeley: University of California Press.

Murray, A.S. \& A.G. Wintle. 2000. Luminescence dating of quartz and improved single-aliquot regenerative-dose protocol. Radiation Measurements 32: 57-73. https://doi.org/10.1016/S1350-4487(99)00253-X

Pacheco, M.L.A.F. 2009. Zooarqueologia dos sítios arqueológicos Maracaju, MS e Santa Elina, MT. Unpublished MA dissertation, Museu de Arqueologia e Etnologia da Universidade de São Paulo.

Reimer, P.J., E. Bard, A. Bayliss, J.W. Beck, P.G. Blackwell, C. Bronk Ramsey, C.E. Buck, H. Cheng, R.L. Edwards, M. Friedrich, P.M. Grootes, T.P. Guilderson, H. Haflidason, I. Hajdas, C. Hatté, T.J. Heaton, D.L. Hoffman, A.G. Hogg, K.A. Hughen, K.F. Kaiser, B. Kromer, S.W. Manning, M. Niu, R.W. Reimer, D.A. Richards, E.M. Scott, J.R. Southon, R.A. Staff, C.S.M. Turney \& J. van Der Plicht. 2013. IntCal13 and Marine13 radiocarbon age calibration curves $0-50,000$ years cal BP. Radiocarbon 55: 1869-97. https://doi.org/10.2458/azu_js_rc.55.16947

Ross, J.L.S. 2005. Contexto geomorfológico do sítio de Santa Elina, in A. Vilhena Vialou (ed.) Pré-história do Mato Grosso: Santa Elina: 81-84. São Paulo: Editora da Universidade de São Paulo.

(C) Antiquity Publications Ltd, 2017 
Valladas, H. 2005. Aplicação do método por carbono 14 em espectrometria de massa por acelerador, in A. Vilhena Vialou (ed.) Pré-história do Mato Grosso: Santa Elina: 47-48. São Paulo: Editora da Universidade de São Paulo.

VIALOU, D. 2005. Representaçôes rupestres, in A. Vilhena Vialou (ed.) Pré-história do Mato Grosso: Santa Elina: 245-54. São Paulo: Editora da Universidade de São Paulo.

- (ed.). 2011. Peuplements et préhistoire en Amériques. Paris: CTHS.

Vilhena Vialou, A. 1997-1998. Une pendeloque taillée dans un os de Glossotherium, in Encyclopaedia universalis: 267. Paris: Universalia.

- 2003. Santa Elina rockshelter, Brazil: evidence of the coexistence of man and Glossotherium, in L. Miotti, M. Salemme \& N. Flegenheimer (ed.) Where the south winds blow: ancient evidence of Paleo South Americans: 21-28. College Station: Center for the Study of the First Americans, Texas A\&M University.
- (ed.). 2005. Pré-história do Mato Grosso: Santa Elina. São Paulo: Editora da Universidade de São Paulo.

- 2007. Metodologia de análise para as indústrias líticas do Pleistoceno no Brasil Central, in L. Bueno \& A. Andrei Isnardis (ed.) Das pedras aos homens: tecnologia lítica na arqueologia brasileira: 173-92. Brasilia: CAPES.

- 2011. Occupations humaines et faune éteinte du Pléistocène au centre de l'Amérique du sud: l'abri rupestre Santa Elina, Mato Grosso, Brésil, in D. Vialou (ed.) Peuplements et préhistoire en Amériques: 193-208. Paris: CTHS.

Vilhena Vialou, A., T. Aubry, M. Benabdelhadi, C. Cartelle, L. Figuti, M. Fontugne, M.E. Solari \& D. Vialou. 1995. Découverte de Mylodontinae dans un habitat préhistorique daté du Mato Grosso (Brésil): l'abri rupestre de Santa Elina. Comptes Rendus de l'Academie des Sciences de Paris 320 (série IIa): 655-61.

Received: 21 March 2016; Accepted: 20 June 2016; Revised: 16 August 2016 